\title{
リポソームの機能と医薬への応用
}

\author{
菊池 寛 \\ エーザイ株式会社 製剤研究部DDS研究室 \\ 干 300-2635 茨城県つくば市東光台 5-1-3
}

\section{Unlimited Potential of Liposomes and Their Application to Medical Field}

\author{
Hiroshi Kikuchi \\ DDS Research, Formulation Research Laboratories, Eisai Co., Ltd., \\ 5-1-3,Tokodai,Tsukuba-shi, Ibaraki 300-2635, Japan
}

It was previously considered that the practical application of liposomal medicines was very difficult. The pharmaceutical technologies for mass production, long term stability during storage, encapsulation efficiency of the drug, etc. were seemed big problems to be solved, and it was well known that the liposomal particles are apt to be entrapped in vivo by the reticuloendothelial system (RES) such as liver, spleen, etc. Fortunately, owing to the progress of science, about 10 liposomal medicines containing the anticancer agents, the antifungal agents, etc. were launched out and are now contributed to medical treatment in the world.

Recently liposomes are expected to be useful as the vectors for in vivo nucleic acid (plasmid DNA, siRNA, etc.) therapy and as the tools for target validation in the area of drug discovery. There are already many liposomal reagents for transfection, and some clinical trials are performed using liposomes.

It is considered that liposomes, the membrane-structure particles, have unlimited potential in the medical field.

Key words : liposomes $/$ DDS (drug delivery system) $/$ targeting $/$ slow release $/$ EPR (enhanced permeability and retention) effect $/$ nucleic acid delivery

\section{1. はじめに}

リン脂質を水に分散させ，ゲル・液晶相転移温度 （Tc）以上に温めると，Fig. 1に示すようなミエリン 像1）が出現し（この段階では, 脂質二分子膜の枚数 は数千枚である)，更に機械的エネルギーにより攪拌 すると，内部に水相を有する閉鎖小胞を調製するこ とができる。これがいわゆるリポソームであり, 1964年に英国の A.D.Bangham 博士が発見した.

このリポソームは, 生体膜由来のリン脂質を主成

Tel : 029-847-5469

Fax : 029-847-1006

E-mail : h4-kikuchi@hhc.eisai.co.jp
分としていること, 細胞膜と同じく脂質二分子膜を 有し膜中に膜タンパク等を再構成できること, リポ ソーム構造そのものが細胞に似ていることなどから, 当初は生体膜モデルとして利用されていた. その後, 1970 年代に入り, このリポソームの内水相あるいは 膜中に薬物を封入することにより, 薬物そのものの 体内動態が変わり, 主薬理効果を高めたり副作用を 軽減したりすることがわかり，ドラッグキャリアー （当時はまだDDS, drug delivery system という言葉は なかった）として注目されるようになった。リポソ 一ムのDDSとしての歴史は比較的長く, 多くの紆余 曲折があったが, 現在では 10 個のリポソーム医薬品 が世界で発売され，今後も続々と医薬品として実用 化されようとしている. 
本稿では, リポソームの特徴（種類と機能）, リポ ソーム医薬品, 核酸導入用リポソームおよびリポソ ーム化粧品の簡単な紹介をしたい。 なお，調製方法 の詳細については他の総説 $2 \sim 5)$ を参照していただけ れば幸いである。

\section{2. リポソームの種類}

リポソームは構造的には多枚膜リポソーム（1)脂 質二分子膜が玉ねぎ状に重なった多重層リポソーム, MLV (multilamellar vesicle), (2)膜枚数が数枚のオリ ゴラメラリポソーム, OLV (oligolamellar vesicle), (3)リポソーム内に更に数個のリポソームが内包され た multivesicular liposome）がある）と一枚膜リポソ ーム（1)小さな一枚膜リポソーム, SUV（small unilamellar vesicle), (2)大きな一枚膜りポソーム, LUV (large unilamellar vesicle), (3)細胞の大きさに近い巨 大一枚膜リポソーム, GUV (giant unilamelar vesicle) がある）に大別される．SUVとLUVの境は $100 \mathrm{~nm}$ $(0.1 \mu \mathrm{m})$ とされており, 後述のEPR (enhanced permeability and retention) 効果 ${ }^{6)}$ による腫瘍組織等の 病変組織へのターゲティングには粒子径 $50 １ 00 \mathrm{~nm}$ のSUVが用いられる．また，リポソームは徐放性製 剂としての利用も可能であり, 後述のリポソーム医 薬品, DepoCyt / SavedarやDepoDur / DepoMorphine では粒子径 $20 \mu \mathrm{m}$ 前後の multivesicular liposomeが用いられている.

なお，調製方法由来の名称として逆相蒸発法リポ ソーム, REV (reverse-phase evaporation vesicle) が 使われたり, 膜成分由来の名称として不飽和脂肪酸 （unsaturated fatty acid）を用いたufasome, 非イオン 性界面活性剂（nonionic surfactant）を用いた niosome, ウイルスの抗原サブユニットを用いたvirosomeなどが使われたりすることもある.

更に，リポソームの有する機能から $\mathrm{pH}$ 感受性リポ ソーム, 温度感受性リポソーム, 抗体修飾リポソー ム (immuno-liposome), 血中滞留型リポソーム (long-circulating liposome) などの名称が使われるこ ともある.

\section{3. リポソームのDDS としての機能}

リポソームは膜組成を自由に変えることができる ので, DDSとしての様々な機能を持っている．低分 子薬物から核酸などの高分子薬物まで保持可能な薬 物が多いこと，様々な膜組成，すなわち物性を有す るリポソーム調製が可能であること（このことがリ ポソームの処方設計を難しくしているともいえる

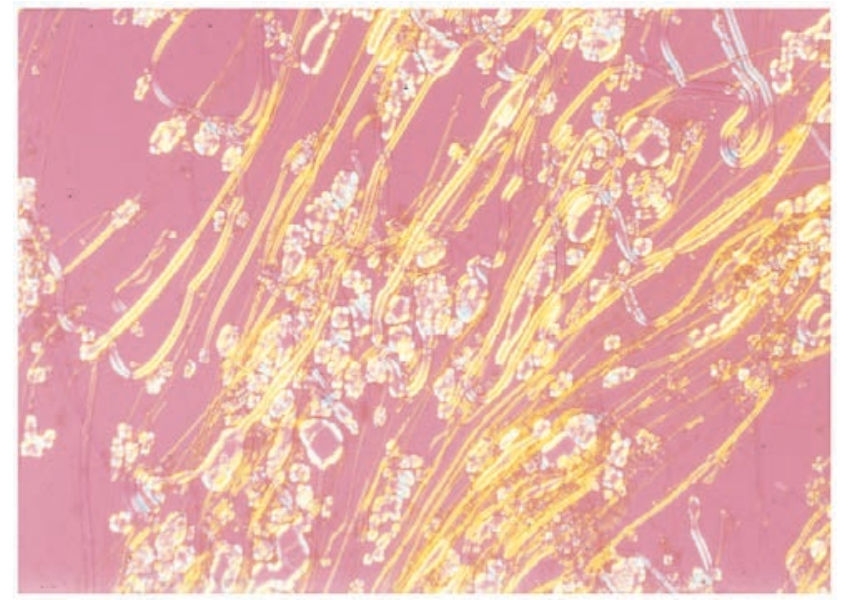

Fig. 1 Typical myelin figure of phospholipid dispersed in water.

が), 生体由来の脂質を主成分とするので生体適合性 がよいこと, 全身投与から局所投与まで考えられる 全ての投与ルートが可能であることなど, リポソー ムの利点は数多くあるが, 詳細は他の総説 $2 \sim 5,7,8)$ を 参照されたい。 ここでは脂質の会合体形成能と薬物 保持, 脂質二分子膜のバリアー能と薬物保持, 温度 感受性あるいは $\mathrm{pH}$ 感受性リポソーム, アクティブタ ーゲティングとパッシブターゲティングについて少 し詳しく紹介する.

\section{1 脂質の会合体形成能と薬物保持}

界面活性剂やリン脂質などの両親媒性物質には臨 界ミセル濃度 $(\mathrm{cmc})$ があるが, 通常の界面活性剤の 場合には $10^{-2} \sim 10^{-4} \mathrm{M}$ であるのに対して, リン脂質 の場合には $10^{-8} \sim 10^{-10} \mathrm{M}$ である ${ }^{3)}$.このことは, リ ン脂質を主成分とするリポソームにとって大きなメ リットになっている. 何故ならば, リポソームはリ ン脂質濃度で $5 \sim 20 \mathrm{mM}$ で調製する場合が多いが, これを生体内に投与して血液や体液で希䣋されても 十分にその $\mathrm{cmc}$ 濃度以上を維持することになり, 結 果としてその構造を体内で維持すること（即ち, 封 入した薬物を安定に保持すること）になる.また， 血中で滞留している間, あるいは EPR効果で病変組 織に分布した後は, 血液・体液に曝されることによ り (希釈効果により), 単分子分散白分子会合体（リ ポソーム状態）の平衡状態がずれながらリポソーム 構造を消失させ, 封入していた薬物を放出すること になる。一方, 通常の界面活性剤の場合には（注： いわゆる高分子ミセルの場合には cmcはもっと低い と思われるので, これには当てはまらない), 例えば 難水溶性薬物を可溶化した状態で製剤としてはミセ ル構造（分子会合体）を形成していても, 血液・体 
液で希採されることにより速やかにその構造を消失 させて薬物を放出することになる，したがって，両 親媒性物質が分子会合体として薬物を保持していて も，通常の界面活性剂ミセルの場合には，保持した 薬物本来の体内動態を変えることはない.

なお, 上記分子会合体の挙動は物理化学的側面か らのものであり, 実際には血液・体液中のリパーゼ 等の酵素の影響も受けるので，もう少し複雑なもの となる。

\section{2 脂質二分子膜のバリアー能と薬物保持}

用いる脂質の種類（アルキル基の長さ，その不飽 和度，時に極性基の種類により Tcが異なる）や膜安 定化物質であるコレステロールの有無により，二分 子膜のバリアー能（物質透過性）は異なるが，一般 論としては，分子量 1,000 前後が二分子膜（生体膜も 含む）透過性における物質の大きさの境界とされて いる. つまり, 分子量 1,000 以下の物質（水分子や 種々の電解質, あるいは薬物も含めて) であれば, 二分子膜が液晶状態（流動性を有する状態）の時に は膜を透過することになるが，膜がゲル状態（流動 性の無い状態）の時には物質透過は起きにくくなる.

また分子量が 1,000 以上の物質の場合には，その分 子の大きさのために膜の流動性にかかわらず膜透過 は起きにくくなる. つまり, 何らかの手段で分子量 1,000 以上の薬物をリポソーム内水相に封入できれ ば，リポソーム膜が物理的エネルギー（希釈効果も 含む）や酵素反応等で破壊されない限り, 内封され た薬物は緩衝液・血液・体液中でリポソーム外水相 には漏れないことになる.

この脂質二分子膜のバリアー能を利用すれば，リ ポソームの内外水相の $\mathrm{pH}$ を変えることも可能であ る. 例えば, 内水相 $\mathrm{pH}$ を酸性に, 外水相 $\mathrm{pH}$ を中性

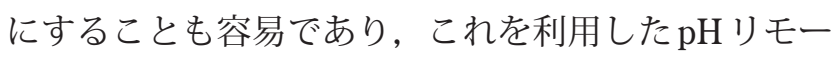
トローディング法 ${ }^{9 ）}$ という塩基性薬物のリポソーム 内水相への高保持率化方法が開発され，実際のリポ ソーム医薬品のいくつかで利用されている.

\section{3 温度感受性リポソーム}

$\mathrm{Tc}$ が $41^{\circ} \mathrm{C}$ のジパルミトイルホスファチジルコリン （DPPC）を主体とした膜成分でリポソームを調製す ると，体温である $37^{\circ} \mathrm{C} て ゙ は$ 膜がゲル状態であるため に内封した薬物を放出せず， $42^{\circ} \mathrm{C}$ 以上になるとリポ ソーム膜が液晶状態になって膜透過性が高まり, 内 封した薬物を濃度勾配によってリポソーム外に放出 させることができる。これが温度感受性リポソーム である，温熱療法と組み合わせることが期待される が，まだ医薬品としては実用化されていない，膜安
定化剤であるコレステロールを添加すると温度感受 性が鈍くなること, 米国では温熱療法そのものが医 療現場でそれほど汎用されていないことなどが理由 として挙げられるが, 新たな脂質原材料の創出や別 の医療機器との組合せなどが期待される.

\section{$3.4 \mathrm{pH}$ 感受性リポソーム}

ジオレオイルホスファチジルエタノールアミン （DOPE）は, 他のリン脂質と異なり, 極性部（親水 部）よりも非極性部（疎水部）の方が大きいコーン 型分子 ${ }^{2)}$ に属し, 周りの環境の $\mathrm{pH}$ やイオン強度によ り会合状態が変化する.このDOPEを主成分とする リポソームは $\mathrm{pH}$ 感受性リポソームとよばれ, 弱酸性 領域（正常組織よりやや pHが低い病変組織, あるい は細胞内小器官であるリソソーム内）で膜透過性が 高まって内封した薬物を放出したり, 膜融合性が高 まったりする. 後述の核酸導入用リポソームの多く はこのDOPEを含んでいるが, リポソームが細胞に エンドサイトーシス (多くのリポソームの場合, 細 胞との融合は起こらないようである）で取り込まれ た後, エンドソーム膜あるいはリソソーム膜と相互 作用し, 内封した核酸を細胞質に放出する際にこの DOPEが重要な役割を果たしている.

\section{5 アクティブターゲティング}

細胞は種々の受容体（レセプター）を有しており， これに対するリガンドでリポソーム膜表面を修飾す れば,アクティブターゲティングが可能となる。こ こでは簡単に例示するが, リポソーム膜表面上での 各膜修飾物質の立体配置や密度などが重要な因子と なっている. また, リポソームが受容体認識で細胞 内に取り込まれる場合には, リポソーム内に封入さ れた薬物はリポソームごと細胞内に取り込まれるこ とになる. 即ちリポソームがエンドソーム, リソソ 一ム経由で消化されてから, 封入された薬物は細胞 質内に入り达む経緯をとる.

\subsection{1 ガラクトース修飾リポソーム}

肝実質細胞にはガラクトース受容体があるので, リポソーム膜を乳糖モノ脂肪酸アミド/エステル 10 ) で修飾することにより, 静注後, 肝実質細胞に到達 させることができる。なお，肝実質細胞入り口には sinusoidal wall という内皮細胞の壁があり，この壁に ある隙間（孔）を通過して肝実質細胞に到達させる ことになるので, リポソームの粒子径は最大でも $200 \mathrm{~nm}$ 以下にする必要がある.

\subsection{2 マンノース修飾リポソーム}

肝クッパー細胞やマクロファージにはマンノース 受容体があるので, リポソーム膜をマンノビオース 
Table 1 Liposomal medicines launched out in the world (September 2009)

\begin{tabular}{|c|c|c|c|c|c|c|}
\hline 商 品 名 & 開発 - 販壳会社 & 薬 剂 & $\begin{array}{c}\text { 脂質組成 } \\
\text { (製剤 } の \text { 形態) }\end{array}$ & \begin{tabular}{|l|} 
世界での \\
上市時期
\end{tabular} & $\begin{array}{l}\text { 日本での } \\
\text { 上市時期 }\end{array}$ & 備 \\
\hline AmBisome & Vestar/NeXstar/Gilead & Amphotericin B & $\begin{array}{l}\text { HSPC/cholesterol/ } \\
\text { DSPG/ } \alpha \text {-tocopherol } \\
\text { (凍結乾燥製剂) }\end{array}$ & 1990 年 & $\begin{array}{c}2006 \text { 年 } \\
\text { (16年遅れ) }\end{array}$ & $\begin{array}{l}\text { 世界初のリポソーム製剤。世界45ヶ国以上で } \\
\text { 上市. 日本では大日本住友製薬が開発. }\end{array}$ \\
\hline $\begin{array}{l}\text { Amphoted } \\
\text { Amphocil }\end{array}$ & $\begin{array}{l}\text { LTI/Sequus/ALZA,J\&J/ } \\
\text { Zeneca }\end{array}$ & Amphotericin B & $\begin{array}{l}\text { cholesteryl sulfate } \\
\text { (凍結乾燥製刜) }\end{array}$ & 1993年 & - & $\begin{array}{l}\text { cholesteryl sulfateとのモル比1：1のコンプ } \\
\text { レックス製剂.世界20ヶ国以上で上市. }\end{array}$ \\
\hline Abelcet & TLC/Elan/Enzon & Amphotericin B & $\begin{array}{l}\text { DMPC/DMPG } \\
\text { (水分散製剂) }\end{array}$ & 1995年 & - & $\begin{array}{l}\text { 脂質 }(\mathrm{DMPC} / \mathrm{DMPG}=7: 3) \text { とのモル比 } 1: 10 \\
\text { コンプレックス製剂。世界26ヶ国以上で上 } \\
\text { 市. }\end{array}$ \\
\hline DaunoXome & $\begin{array}{l}\text { Vestar/NeXstar/Gilead/ } \\
\text { Diatos }\end{array}$ & Daunorubicin & $\begin{array}{l}\text { DSPC/cholesterol } \\
\text { (水分散製用) }\end{array}$ & 1995年 & - & $\begin{array}{l}\text { DSPC/cholesterol 処方リポソーム。 世界34ヶ } \\
\text { 国以上で上市。カポジ肉腫での 1st-line } \\
\text { treatment. }\end{array}$ \\
\hline $\begin{array}{l}\text { Doxil/ } \\
\text { Caelyx }\end{array}$ & $\begin{array}{l}\text { LTI/Sequus/ALZA,J\&J/ } \\
\text { Ortho, Schering-Plough }\end{array}$ & Doxorubicin & $\begin{array}{l}\text { HSPC/cholesterol/ } \\
\text { MPEG-DSPE } \\
\text { (水分散製斉) }\end{array}$ & 1995年 & $\begin{array}{c}2007 \text { 年 } \\
\text { (12年遅狆) }\end{array}$ & $\begin{array}{l}\text { ステルスリボソーム，世界80ヶ国以上で上 } \\
\text { 市。米国ではOrtho(Tibotec)がDOXILで、欧 } \\
\text { 州ではSchering-PloughがCAELYXで骐売. }\end{array}$ \\
\hline $\begin{array}{l}\text { DepoCyt/ } \\
\text { Savedar }\end{array}$ & $\begin{array}{l}\text { SkyePharma/Enzon(US), } \\
\text { Mundipharma(EU) }\end{array}$ & AraC & $\begin{array}{l}\text { DOPC/cholesterol/ } \\
\text { DPPG/triolein } \\
\text { (水分散製剂) }\end{array}$ & 1999年 & - & $\begin{array}{l}\text { マルチバジクルリポソームで } 2 \text { 週間に一度投 } \\
\text { 与の徐放性製剂. CSF八の直接注入によるリ } \\
\text { ンハ腫性䯣膜炎治療. 欧米加で上市. }\end{array}$ \\
\hline Myocet & TLC/Elan & Doxorubicin & $\begin{array}{l}\text { eggPC/cholesterol } \\
(\text { (アバイアルキッ製品) }\end{array}$ & 2001年 & - & $\begin{array}{l}\text { eggPC/cholesterolりポソーム. 欧州主要国で上 } \\
\text { 市. 主薬ドキソルビシンの封入は } \mathrm{pH} \text { 勾配法を使 } \\
\text { 用し,ベッドサイドで調製する方法. }\end{array}$ \\
\hline Visudyne & QLT/Novartis & Verteporfin & $\begin{array}{l}\text { eggPG/DMPC } \\
\text { (凍結乾燥製剂) }\end{array}$ & 2001年 & $\begin{array}{c}2004 \text { 年 } \\
(3 \text { 年遅れ) }\end{array}$ & 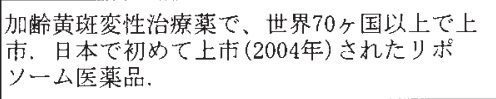 \\
\hline $\begin{array}{l}\text { DepoDur/ } \\
\text { DepoMorphine }\end{array}$ & SkyePharma/Endo & Morphine & $\begin{array}{l}\text { DOPC/cholesterol/ } \\
\text { DPPG/triolein } \\
\text { (水分散製剂) } \\
\end{array}$ & 2004年 & - & 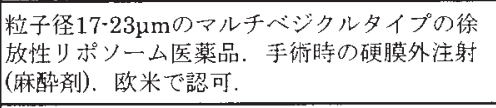 \\
\hline Marqibo & Hana Biosciences & Vincristine & SM/cholesterol & 2008年 & - & 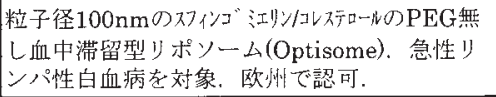 \\
\hline
\end{tabular}

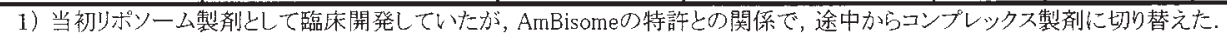

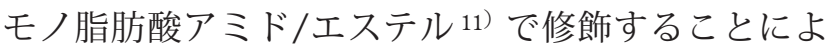
り, 静注後, これら細胞に到達させることができる. なお，こちらの場合には, 粒子径は大きめの方が細 胞への取り达みは効率がよいとされている.

\subsection{3 ホスファチジルセリン修飾リポソーム}

同様に，肝クッパー細胞やマクロファージにはリ ン脂質の一つであるホスファチジルセリン（PS）受 容体があるので, PS主体のリポソームは静注後に単 球やマクロファージへの取り达みが増大する。実用 化には至らなかったが, 1980 年代には免疫賦活剂で あるムラミルペプチド誘導体封入 PSリポソームの研 究が外資系大手製薬企業により盛んになされた。

\subsection{4 アミノ酸・ペプチド修飾リポソーム}

リポソーム表面をアルギニンで修飾すると腫瘍細 胞に取り达まれやすいことは以前からわかってい た 12) が，近年はアルギニンが 8 個結合したポリアル ギニンが注目されており，これが核酸の細胞内導入 や薬物のミトコンドリアへの送達 13) に有用であるこ とが示唆されている。また，腫瘍新生血管に親和性 のあるペプチド修飾リポソーム 14）の研究も興味深い ところである。

\subsection{5 トランスフェリン修飾リポソーム}

多くの腫瘍細胞にはトランスフェリン受容体があ
るので, これを利用したトランスフェリン修飾リポ ソーム 15) の研究もなされている. 近年, 国内ベンチ ヤー企業によりこのリポソームの臨床試験が米国で なされており, その結果が注目される.

\subsection{6 葉酸修飾リポソーム}

トランスフェリンと同様, 腫瘍細胞には葉酸受容 体があることもわかっており, これを利用した葉酸 修飾リポソーム16) の研究も行われている.

\subsection{7 抗体修飾リポソーム}

上記のアクティブターゲティング用リポソームの 場合には，必ずしも標的とする細胞だけがその受容 体を有しているわけではなく, 他の細胞にも同じ受 容体が存在するために, ターゲティング効率は必ず しも高いわけではない。一方, 抗体修飾リポソーム (イムノリポソーム) の場合には，更なるターゲティ ング効率の増加が期待されており, 抗体そのものの 工夫もなされている ${ }^{17,18)}$.

\section{6 パッシブターゲティング}

リポソーム膜をグリコホリンやガングリオシドな どの末端にシアル酸を有す糖タンパク質や糖脂質 ${ }^{19)}$, あるいはポリグリセリン脂質誘導体 20）やポリエチレ ングリコール脂質誘導体 ${ }^{21)}$ で修飾すると，リポソー 
ム膜表面に水和層を形成させることができる，この リポソームは静脈内投与後もこの水和層のために異 物認識されにくくなり, 肝蔵や脾蔵などの細網内皮 系 (RES; reticuloendothelial system) に取り込まれに くくなって, 結果的には血中滞留性を示すことにな る。これを血中滞留型リポソーム (long-circulating liposome）と呼ぶが，更にその粒子径を $50 〜 100 \mathrm{~nm}$ に制御すると腫瘍組織, 感染組織, 炎症組織などの 病変組織にターゲティングすることができるように なる．正常組織では血管内皮細胞が密に並んでおり， リポソームのような微粒子は正常組織にはなかなか 大り込むことができない（副作用の軽減につながる） が，多くの固形腫瘍組織においては，(1)新生血管に よる高い腫瘍内血管密度, (2)不完全な血管構造（血 管内皮細胞同士の間隙が $100 ２ 00 \mathrm{~nm}$ といわれてい る)，(3)様々な血管透過性因子による血管透過性の立 進，(4)リンパ系回収機能不全が起きており，これに よりリポソームなどの微粒子あるいは高分子化医薬 などが腫瘍組織に集積し，また長期間にわたってと ぞまる（抗腫瘍効果の増強につながる）ことが知ら れている ${ }^{22)}$.これを EPR効果 ${ }^{6)}$ とよぶが，マウス， ラット, ヒトでその存在の確認がなされている.

なお，この EPR効果は全ての固形癌に適用できる わけではなく, 肉腫・皮膚癌, 卵巣癌, 乳癌, 肝臓 癌では適用しやすく, 消化器癌では中程度に適用で きまた血管から実組織までの距離が長く周りに結 合組織の多いすい臓癌では適用しにくいといわれて いる. また, 感染組織や炎症組織でも EPR効果は適 用できるが，近年，動脈硬化にも適用できる可能性 が見出されている23).

後述のドキソルビシン封入 PEG 修飾リポソーム, DOXILは代表的なパッシブターゲティング製剤で ある.

\section{4. リポソーム医薬品}

リポソームは 1970 年代からドラッグキャリアーと して注目された（当時も論文数, 出願特許数は最も 多かった）が，大量生産方法（均一性・再現性保証, 無菌性保証も含む), 長期保存安定性保証, 水溶性薬 物の高保持率化などの製剂工学的問題点, あるいは RESに捕捉されやすいという生物学的問題点のため に医薬品としての実用化は不可能であろうといわれ ていた。しかしながら, 現在ではこれらの問題点は ほぼ解決されて, Table 1 に示すリポソーム医薬品が 世界で発売されて医療に貢献している。

どのように製剤工学的問題点が解決されたのか, その詳細は他の総説 ${ }^{2}$ 5) に譲るが, ここではリポソ

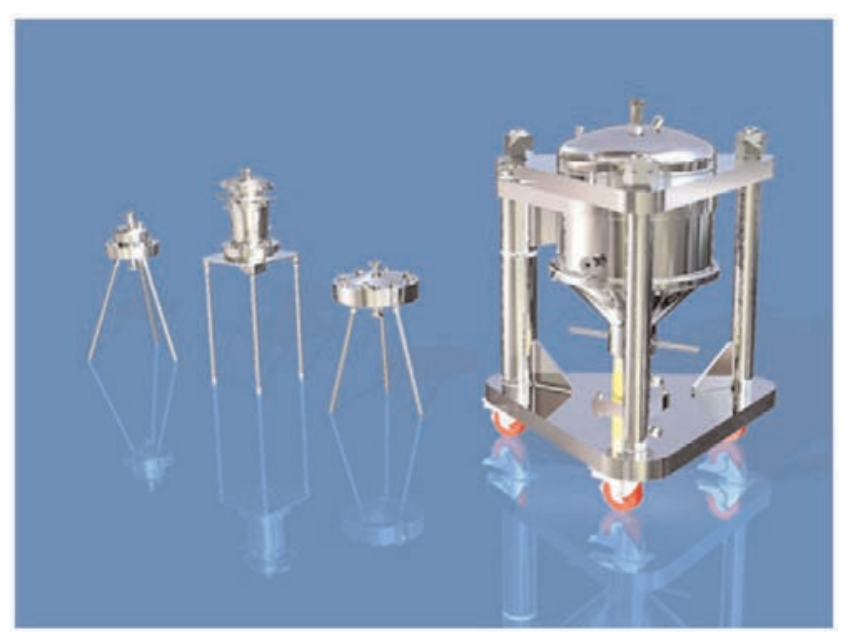

Fig. 2 Liponizer ${ }^{\circledR}$ for control of liposomal particle size. These are for $90 \mathrm{~mm} \phi, 90 \mathrm{~mm} \phi$ (with $500 \mathrm{~mL}$ tank), $142 \mathrm{~mm} \phi$ and $293 \mathrm{~mm} \phi$ membrane filter from the left.

ームの粒子径を制御するために筆者らが開発した高 圧整粒器リポナイザー (Fig. 2参照;野村マイクロサ イエンス（株）製造，日油（株）販売）の紹介をし たい.リポソームの粒子径を制御することはその体 内動態制御の観点からも重要な要素である. 薬物や 脂質が熱や機械的せん断力に安定な場合には, 通常 のホモジナイザーで粗乳化したリポソーム分散液を 更にマントンガウリン型乳化機のような高圧ホモジ ナイザーを使用すればよいが，そうでない場合には， 均一孔径を有するメンブランフィルターにリポソー 厶分散液を高圧下で通す extrusion 法 ${ }^{24)}$ が便利である が, Fig. 2のリポナイザーはそのための装置である.

Table 1 に示す個々のリポソーム医薬品の詳細は他 の総説 ${ }^{25,26)}$ を参照していただきたいが，既に 10 個の 医薬品が実用化されている。ここで気づくのは, 1）加齢黄斑変性治療薬Visudyne を除くと，いずれ も既存薬をリポソームでDDS化し, 初期は大学発の ベンチャー企業が開発し, 途中から大手製薬企業が 引き継いだこと，2）日本の場合には，承認されたリ ポソーム医薬品が 3 品目しかなく, また新薬をリポソ 一ム化した Visudyneを除くと, 世界の上市から 16 年 (AmBisome) ないし 12 年（Doxil）も遅れて日本で 承認されたことである.

後者の原因としては, (1)創薬研究の大きなパラダ イムシフト, (2)外資系グローバル企業の日本への攻 勢, (3)日本はベンチャー企業が育ちにくい環境, (4) 日本はパイロット的な臨床薬理試験（探索的薬理試 験）が実施しにくい環境，(5)市場性・国民性の違い, (6)薬価制度の問題, (7)新規添加物の安全性試験の問 題, 8)混合診療の問題, (9ガイドライン/ガイダンス 
Table 2 Liposomal reagents for delivery of nucleic acids (September 2009)

\begin{tabular}{|c|c|c|c|}
\hline 商品名 & 開発 · 販 売会社 & 脂質組成 & 满 考 \\
\hline Lipofectin & Invitrogen ${ }^{a)}$ & DOTMA $^{11}:$ DOPE $^{2)}=1: 1$ (重量比) & 水分散製戍，血清存在下で不安定. \\
\hline Lipofectamine & Invitrogen & $\operatorname{DOSPA}^{3)}:$ DOPE $=3: 1$ (重量比) & 水分散製戍, 血清存在下で不安定. \\
\hline DIMRIE-C & Invitrogen & DIMRIE $^{4)}:$ cholesterol = 1:1 (モル比) & 水分散製剂，血清存在下で使用可. \\
\hline Lipofectamine2000 & Invitrogen & 組成は不詳 & 水分散製剂，血清存在下で使用可. \\
\hline Oligofectamine & Invitrogen & 組成注不詳 & 水分散製剂，アンチセンスオリゴ用 \\
\hline Lipofectamine LTX / RNAiMAX & Invitrogen & 組成は不詳 & 水分散製剂，血清存在下で使用可. \\
\hline Invivofectamine & Invitrogen & 組成俚不詳 & 水分散製剂，血清存在下で使用可. \\
\hline DOTAP & Roche Applied Science & DOTAP $^{5)}$ & 水分散製剤，血清存在下で不安定. \\
\hline DOSPER & Roche Applied Science & DOSPER $^{6)}$ & 水分散製剂，血清存在下で不安定. \\
\hline Transfectam & Promega & DOGS $^{7)}$ & 脂質粉末, 血清存在下で不安定. \\
\hline PerFectin & Genlantis/フナコシ & カチオン脂質は不詳，DOPEは含まれている & 脂質粉末，血清存在下で使用叮。 \\
\hline GeneSilencer & Genlantis/フナコシ & 組成仗不詳 & 水分散製剂，血清存在下で使用可。 \\
\hline HilyMax & 同仁化学 & 組成俚不詳 & 水分散製剂, 血清存在下で使用可. \\
\hline Genetransfer lyo & 名古屋大学 / 和光純薬 & TMAG $^{8)}: \mathrm{DLPC}^{9)}: \mathrm{DOPE}=1: 2: 2$ (モル比) & 凁結乾燥製椷, 血清存在下で使用可。 \\
\hline COATSOME EL-01-D & 第一製菜/日本油脂 & DC-6-14 ${ }^{10)}:$ DOPE:cholesterol $=4: 3: 3$ (モル比) & 凍結乾燥製凧，血清存在下で使用可。 \\
\hline LipoTrust SR / PE / CH & 第一製葲 / 北海道システム・サイインス & $\begin{array}{l}\text { DC-6-14:DOPE: cholesterol } \\
=4: 3: 3,5: 2: 0,5: 0: 2 \text { (モル比) }\end{array}$ & 凍結乾燥製剂，血清存在下で使用可。 \\
\hline LipoTrust EX Gene / Oligo & 第一製薬 / 北海道シスデム・少イエンス & 組成牥不詳 & 凍結乾喿製剂, 血清存在下で使用可. \\
\hline
\end{tabular}

a) Invitrogen社とApplied Biosystems社が2008年11月に合併し, Life Technologies社に社名変更

1) N-[1-(2,3-dioleyloxy) propyll-N,N,N-trimethylammonium chloride, モノカチオニック脂質

2) dioleoylphosphatidyletanolamine

3）2,3-diolexyoloxy-N-[2(spermine carboxamido)ethyl]-N,N-dimethyl-1-propanammonium trifluoroacetate，ポリカチオニック脂質

4) 1,2-dimyristyloxypropyl-3-dimethyl-hydroxy ethylammonium bromide, モノカチオニック脂質

5) Lipofectin 原料の DOTMAの chloride が methyl-sulfateに変わったもの，飞ノカチオニック脂質

6) 1,3 -dioleoyloxy-2・(6・carcoxy"spermyl)-propylamid tetraacetate, ポリカチタニック脂質

7) dioctadecylamidoglycyl spermine trifluoroacetate, ポリカチオニック脂質

8) $\mathrm{N}$-( $\alpha$-trimethylammonioacetyl)-didodecyl-D-glutamate chloride，モノカチオニック脂質

9) dilauroylphosphatidylcholine

10) O,O'-ditetradecanoyl-N-( $\alpha$-trimethylammonioacetyl) diethanolamine chloride, モノカチオニック脂質

が無いこと, などの日本特有の問題点が挙げられ る 27, 28).このうち(4)，(6)，7， 8)，(9)はレ゙ュレー ション関係の問題であるが,「ナノテクノロジー」の キーワードのもと，日本政府の努力により近年これ らはかなり改善されてきており, 今後は日本でも既 存薬のDDS（特にリポソームはナノテクノロジーの 代表格である）は積極的に開発されていくことが期 待される.

\section{5. 核酸導入用リポソーム}

プラスミドDNA，siRNAなどの核酸を細胞内に導 入するべクターとしては, 種々のウイルスのほかに 非ウイルス系と呼ばれるものがある. 非ウイルス系 はウイルスに比べて安全性では優るものの, 細胞内 導入効率の面ではウイルスに劣るとされていた。し かしながら, 近年は種々の改良が施され, 非ウイル ス系も細胞内導入効率の面でウイルス並みになった とされる. 非ウイルス系の中で最も盛んに検討され ているのがリポソームである. Table 2 に代表的な核 酸導入用リポソーム試薬を示すが, 基本的にはモノ カチオン脂質あるいはポリカチオン脂質が主成分と
して使われ，更に前述のDOPEが含まれる場合が多 い. 核酸が電気的に負電荷を有し，また細胞膜表面 自体も負電荷であるために, カチオン脂質が広く利 用されている.

なお，初期の頃の核酸導入用リポソームは，in vitro 核酸導入時にいったん無血清培地に置換え, 一 定時間後に再び血清添加培地に置き換えるという煩 雑な作業を必要とし, またin vivoでの効果も期待で きなかった. 筆者らは, 核酸そのものが血清で分解 されるためではなく（むしろ，カチオニックリポソ ームとコンプレックスを形成することにより, 血清 に対して安定化する), リポソーム構造そのものが血 清により破壊されること, これを防ぐには膜安定化 剤であるコレステロールを添加すればよいことを明 らかにした $\left.{ }^{29}, 30\right)$. 最近のリポソーム試薬はみなコレ ステロールが添加されているために, 血清存在下で も使用可となっている.

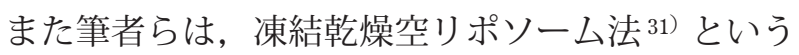
新規なリポソーム調製方法を以前から開発していた が，これが核酸含有リポソームの調製には非常に有 用であることも見出した ${ }^{32}$ が，この方法は Table 2 掲載のリポソーム試薬のいくつかでも利用されて 


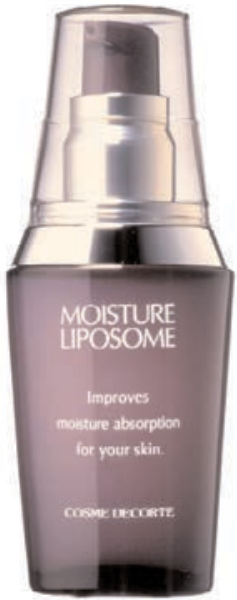

Fig. 3 Liposomal cosmetic named COSME DECORTE, "MOISTURE LIPOSOME".

(This photograph was kindly supplied from Kose Corporation)

いる.

核酸導入用リポソームは, (1)標的のバリデーショ ン等の創薬のツールとして，あるいは(2)核酸治療薬 のベクターとして用いられるが，現在リポソームを 用いた臨床試験も多くなされており，近い将来，核 酸医薬の世界でもリポソーム医薬品が実用化される ことが期待される。

\section{6. リポソーム化粧品}

リポソームは内水相を有し（したがって水を保有 したマイクロカプセルともいえる), 細胞の大きさ （一般的には $10 \mu \mathrm{m}$ 前後である）と比べるとはるかに 小さい。したがって，これを皮膚に適用すると皮膚 表面での保湿効果の増強や延長効果が期待でき，ま た更に，内水相や二分子膜中に栄養成分を添加する ことによりプラス $\alpha$ の効果も期待される. このため に，1980年代から欧米を中心にリポソーム化粧品と 銘打った製品が発売されていたが，当時のものは純 度の低い（油分の多い）レシチンを用いている場合

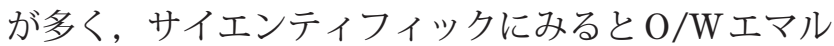
ションであった。その後，1990年前後からは化粧品 の世界でも本物のリポソーム化粧品が発売されるよ うになったが，Fig. 3 は 1992 年に発売になった国産 のリポソーム化粧品である.

\section{7. まとめ}

脂質二分子膜により形成され内部に水相を有する 閉鎖小胞，即ちリポソームは，生体膜モデルとして
ばかりでなく，DDSの一つとしても注目され，既に 医薬品あるいは化粧品としても実用化されている. 今は核酸の細胞内導入用試薬としても用いられてい るが，この核酸医薬の領域でも近い将来，リポソー 么医薬品が実用化され，医療に貢献するであろう。

\section{謝 辞}

遺伝子導入用試薬のリスト作りでご協力をいただ いた北海道システム・サイエンス（株）DDS部長中 野善郎工学博士, 化粧品リポソームの写真をご提供 くださいました (株) コーセー執行役商品開発部長荒 金久美薬学博士，並びに同取締役研究所長内藤昇工 学博士に感謝いたします。

\section{文 献}

1）菊池 寛: Food \& Food Ingredients Journal of Japan, 210, 426-436 (2005)

2) 菊池 寛, 井上圭三 : 細胞工学，2, 1136-1150 (1983)

3) 山内仁史，菊池 寛：フレグランス・ジャーナル， No.87, 68-76 (1987)

4) 菊池 寛 : PHARM TECH JAPAN, 19, 99-110, 419-433 (2003)

5）菊池 寛 : 注射剂 (特殊製剂), 『20 周年記念版 製剂機 械技術ハンドブック（製剂機械技術研究会編集）』，地 人書館, 印刷中

6) Matsumura Y, Maeda H : Cancer Res., 46, 6387-6392 (1986)

7) 菊池 寛，井上圭三 : 油化学，34, 784-798 (1985)

8）菊池 寛: リポソーム製剂, 『ドラッグデリバリーシス テムの新展開 : 究極の薬物治療を目指して（永井恒司 監修)』，シーエムシー出版，pp.173-184 (2004)

9) Mayer LD, Bally MB, Cullis PR : Biochim. Biophys. Acta, 857, 123-126 (1986)

10) Yamauchi H, Kikuchi H, Sawada M, Tomikawa M, Hirota S : J. Microencapsulation, 11, 179-188, 287-296 (1994)

11) Yachi K, Kikuchi H, Yamauchi H, Hirota S, Tomikawa M : ibid., 12, 377-388 (1995)

12) 富川宗博, 広田貞雄, 山内仁史, 菊池 寛, 川戸康義 : 日本国特許第 2786482 号

13) Yamada $Y$, Akita H, Kamiya H, Kogure K, Yamamoto $T$, Shinohara Y, Yamashita K, Kobayashi H, Kikuchi H, Harashima H : Biochim. Biophys. Acta, 1778, 423-432 (2008)

14) 浅井知浩, 奥 直人 : Drug Delivery System, 19, 488-494 (2004)

15) 丸山一雄, 柳衛宏宣, 安藤秀一, 菊池 寛 : 特願平 11172176 号

16) Gabizon A, Horowitz AT, Goren D, Tzemach D, Shmeeda H, Zalipsky S : Clinical Cancer Res., 9, 6551-6559 (2003)

17) Hatakeyama H, Akita H, Ishida E, Hashimoto $K$, Kobayashi H, Aoki T, Yasuda J, Obata K, Kikuchi H, Ishida T, Kiwada H, Harashima H : Int. J. Pharm., 342, 
194-200 (2007)

18) Atobe $K$, Ishida $T$, Ishida $E$, Hashimoto $K$, Kobayashi $H$, Yasuda J, Aoki T, Obata K, Kikuchi H, Akita H, Asai T, Harashima H, Oku N, Kiwada H : Biol. Pharm. Bull., 30, 972-978 (2007)

19) Yamauchi H, Kikuchi H, Yachi K, Sawada M, Tomikawa M, Hirota S : Int. J. Pharm., 90, 73-79 (1993)

20) Maruyama K, Okuizumi S, Ishida O, Yamauchi H, Kikuchi H, Iwatsuru M : ibid., 111, 103-107 (1994)

21) Allen TM, Hansen C, Martin F, Redemann C, Yau-Young A : Biochim. Biophys. Acta, 1066, 29-36 (1991)

22) 菊池 寛: Biotherapy, 18, 353-360 (2004)

23) Takahama H, Minamino T, Asanuma H, Fujita M, Asai T, Wakeno M, Sasaki H, Kikuchi H, Hashimoto K, Oku N, Asakura M, Kim J, Takashima S, Komamura K, Sugimachi M, Mochizuki N, Kitakaze M : J. American College Cardiology, 53, 709-717 (2009)

24) Olson F, Hunt CA, Szoka FC, Vail WJ, Papahadjopoulos D : Biochim. Biophys. Acta, 557, 9-23 (1979)

25) 菊池 寛：リポソーム製剤の最近の動向，『リポソーム 応用の新展開 : 人工細胞の開発に向けて（秋吉一成, 辻井薰監修)』, エヌ・ティー・エス, pp.632-642 (2005)

26) 菊池 寛: 実用化されたリポソーム医薬品と今後の展 望, 『DDS治療システムの設計と評価 : 未来医療の開拓 に向けて (橋田充編集)』, じほう，2009年 11月発行 予定

27) 菊池 寛: ファルマシア，42, 337-342 (2006)

28) 菊池 寛: ナノD D S の実用化と課題, 『ソフトナノテ クノロジー : バイオマテリアル革命 (田中順三監修)』, シーエムシー出版, pp.278-283 (2005)

29) Kikuchi H, Suzuki N, Morita H, Ishii Y : J. Liposome Res., 8, 68-69 (1998)

30) 菊池 寛: Drug Delivery System, 19, 530-538 (2004)

31) Yachi K, Harashima H, Kikuchi H, Sudoh R, Yamauchi H, Ebihara K, Matsuo H, Funato K, Kiwada H : Biopharm. Drug Dispos., 17, 589-605 (1996)

32) Kikuchi H, Suzuki N, Ebihara K, Morita H, Ishii Y, Kikuchi A, Sugaya S, Serikawa T, Tanaka K : J. Control. Release, 62, 269-277 (1999)

(Received 30 September 2009;

Accepted 2 October 2009)

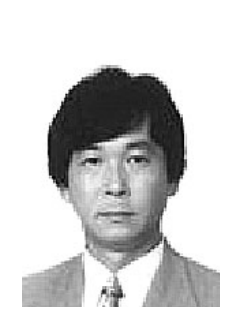

\section{著者略歴}

菊池 寛（きくち ひろし）

1977 年 3 月 東京大学薬学部薬学 科卒業

1977 年 2007 年 第一製薬 (株)

勤務

2007 年〜現在 エーザイ（株）に

転職，現在に至る

1992 年～現在 東京大学薬学部 非常勤講師兼任
2007 年～現在 九州大学大学院薬 学研究院薬物送達シ ステム学講座 客員 教授兼任

2000 年～現在 日本薬剤学会評議 員, 理事(2008 年〜)

2001 年 現在 日本DDS学会評議 員, 監事（2000 年〜)

2002 年〜現在 日本シクロデキス トリン学会 評議員 1991年 2 月 薬学博士号取得 (東 京大学)

1993 年〜 1994 年 ミシガン大学薬 学部留学

1995 年 2009 年 北海道大学大学 院, 京都大学大学院, 岡山大学医学部, 徳 島大学大学院, 九州 大学薬学部等の非常 勤講師歴任 